\title{
PROSES PRODUKSI INDUSTRI PANDAI BESI DI KECAMATAN TOGO BINONGKO KABUPATEN WAKATOBI
}

\author{
Leni $^{\left.{ }^{*}\right)}$, Mardin $^{1)}$ Suriana ${ }^{1)}$ \\ ${ }^{1}$ Department Agricultural Extension Faculty of Agriculture, Universitas Halu Oleo Kendari 93232
}

${ }^{*}$ Corresponding author: lenibinongko21@gmail.com

To cite this article:

Leni, L., Mardin, M., \& Suriana, S. (2021). Proses Produksi Industri Pandai Besi di Kecamatan Togo Binongko Kabupaten Wakatobi. Jurnal IImiah Membangun Desa dan Pertanian, 6(5), 175 - 181. doi:http://dx.doi.org/10.37149/jimdp.v6i5.17854

Received: April 24, 2021; Accepted: December 29, 2021; Published: December 30, 2021

\begin{abstract}
This study aimed to determine the production process of the blacksmith industry in Togo Binongko District, Wakatobi Regency, in May 2019. The determination of the research location was determined purposively. Respondents in this study were heads of families who worked as blacksmiths in Togo Binongko District, Wakatobi Regency, with as many as 20 respondents. Data analysis uses quantitative data analysis techniques to describe the data that has been collected and present the data in tabular form so that it becomes clearer according to the conditions in the field. The results showed that the agricultural equipment produced by the smart in Togo Binongko District was made through a traditional production process while maintaining product quality. The production process starts from Tila and Tihi (sorting and cutting of iron raw materials), Kepa'a (forging), Hokomonde'a (modeling), and Soropu'a (re-burning). Blacksmith artisans can maintain the quality of the products produced by improving the production process by participating in training and using equipment that can increase production efficiency.
\end{abstract}

Keywords: blacksmith industry; production; Togo Binongko District; Wakatobi Regency

\section{PENDAHULUAN}

Usaha kecil mempekerjakan lebih banyak tenaga kerja dengan modal dan peralatan terbatas. Usaha kecil memainkan peran penting dalam pembangunan nasional. Salah satu cara pemerintah untuk meningkatkan kesempatan kerja adalah dengan mengembangan Usaha Mikro, Kecil, dan Menengah (UMKM) karena mampu bertahan bahkan memulihkan perekonomian nasional di tengah krisis keuangan. (Azmi et al., 2015)

Industri pandai besi merupakan salah satu usaha kecil dan termaksud dalam usaha pertukangan besi yng berproduksi hanya berdasarkan kebiasaan saja (Ahya \& Lestari, 2016) Industri pandai besi awalnya membuat senjata tradisional seperti keris, pedang dan parang namun pada perkembangannya usaha pandai besi mulai membuat alat-alat seperti mata pahat, pisau, dan parang yang bisa untuk dikomersilkan dan digunakan untuk keperluan rumah tangga. Selain memproduksi untuk keperluan rumah tangga, industri pandai besi juga memproduksi alat-alat pertanian/perkebunan/perikanan seperti linggis dan parang (Anonim, 20115; Saifuddin et al., 2016; Talakua, 2008) Alat-alat tersebut digunakan oleh masyarakat untuk keperluan bercocok tanam sehingga produk industri pandai besi di Kecamatan Togo Binongko telah dipasarkan ke daerah lain. (Talakua, 2008) dibutuhkan kerja sama antara pengusaha menengah dengan para pengusaha kecil sehingga produksi yang dihasilkan oleh industri pandai besi dapat dipasarkan ke daerah lain

Industri pandai besi di Kecamatan Togo Binongko Kabupaten Wakatobi membutuhkan bahan baku besi dalam setiap produksi sebanyak $30-50 \mathrm{~kg}$ besi yang diperoleh dengan harga perkilogram senilai Rp13.500 sehinga modal yang harus dikeluarkan oleh industri pandai besi sebesar Rp4.050.000 - Rp6.750.000 untuk pembelian bahan baku besi. Industri pandai besi di Kecamatan Togo Binongko dapat menghasilkan 20 produk setengah jadi dalam sehari dan dalam satu bulan dapat menghasilkan 30-50 produk setengah jadi. Sedangkan produk jadi yang dihasilkan hanya sekitar 3-5 produk dalam sehari. Produk pandai besi merupakan bagian yang tidak terpisahkan dari 
kehidupan masyarakat dengan peran yang berbeda-beda, mulai untuk kebutuhan pertanian, rumah tangga, budaya sampai untuk kepentingan ekonomi. Satu mata pisau dipasarkan dengan harga Rp15.000 - Rp20.000 dan untuk satu mata parang khusus perempuan dipasarkan dengan harga Rp30.000 - Rp35.000 sementara satu mata parang khusus laki-laki dipasarkan dengan harga Rp40.000 - Rp50.000. Pendapatan yang diperoleh oleh usaha pandai besi di Kecamatan Togo Binongko dalam sekali pemasaran produk berkisar antara Rp1.000.000 - Rp3.500.000. Produk yang dihasilkan seperti parang dan pisau dijual hingga ke daerah lain di Pulau Buton dan daratan Sulawasi. Masyarakat Kecamatan Togo Binongko telah menjadi pandai besi secara turun temurun dan menganggap industri pandai besi merupakan motor penggerak bagi perekonomian karena mampu memberikan keuntungan dan meningkatkan kesejahteraan keluarga (Sumanti, 2020) Pembinaan terhadap industri pandai besi dapat dilakukan melalui kegiatan pelatihan, magang atau studi banding, pendampingan dan pemberian bantuan peralatan produksi untuk meningkatkan keuntungan usaha (Adiputra, 2020; Azmi et al., 2015; Talakua, 2008)

Pelaku usaha industri pandai besi di Kecamatan Togo Binongko tidak memiliki tanah sendiri, mereka meminjam tanah untuk membuka usaha dan harus pindah jika tanah tersebut diambil kembali oleh pemiliknya, keterbatasan modal untuk menunjang kebutuhan usaha pandai besi, seperti pembelian bahan baku besi, keterbatasan modal dalam usaha pandai besi akan menyebabkan ketidak lancaran proses produksi, tidak adanya partner kerja sehingga produksi pandai besi tidak berjalan lancar karena dilakukan sendiri, sedangkan industri pandai minimal dalam setiap produksi memerlukan dua orang pekerja terampil/mahir dan memiliki kecocokan dalam bekerja, harga jual produk industri pandai besi menjadi tidak menentu/stabil dikarenakan pembeli melakukan penawaran produk tidak sesuai dengan harga yang ditetapkan sehingga pendapatan industri pandai besi tidak sesuai dengan yang diharapkan.

Saifuddin et al. (2016) konsumen mengeluhkan ketidakseragaman produk dan kualitas produk, khususnya pada peralatan pertanian, sehingga tidak dapat bersaing dengan produk dari negara lain. Hasil akhir sangat dipengaruhi oleh keadaan perajin pandai besi yang kurang memahami secara ilmiah dalam memilih bahan dasar dan tata cara penyepuhan (perlakuan panas) yang hanya berdasarkan adat turun temurun. Armila (2018); Saifuddin et al. (2016) industri pandai besi umumnya dilakukan secara turun temurun dengan berbagai macam permasalahan. Berbagai masalah yang dihadapi oleh induatri pandai besi saat ini namum industri pandai besi di Kecamatan Togo Binongko masih tetap bertahan dengan usahanya karena usaha pandai besi adalah mata pencaharian pokok bagi masyarakat Kecamatan Togo Binongko dan telah menjadi mata pencaharian turun temurun dan membudaya dikalangan masyarakat Pulau Binongko dengan proses produksi yang sederhana. Talakua (2008)perbaikan proses produksi akan mempengaruhi pendapatan industri pandai besi. Berdasarkan uraian latar belakang maka tujuan dari penelitian ini adalah untuk mengetahui proses produksi Industri pandai besi di Kecamatan Togo Binongko Kabupaten Wakatobi.

\section{MATERI DAN METODE}

Penelitian ini telah dilaksanakan di Kecamatan Togo Binongko Kabupaten Wakatobi pada bulan Desember 2018. Penentuan lokasi dilakukan secara purposive Sampling dengan pertimbangan bahwa Kecamatan Togo Binongko merupakan pusat industri pandai besi yang ada di Pulau Binongko yang bergerak dalam bidang pengolahan bahan baku besi menjadi alat-alat pertanian/perkebunan seperti parang dan linggis yang dipasarkan di Pulau Binongko dan daratan Sulawesi. Populasi dalam penelitian ini adalah seluruh kepala keluarga yang memiliki usaha pandai besi di Kecamatan Togo Binongko sebanyak $141 \mathrm{KK}$. Penentuan sampel dalam penelitian ini dilakukan dengan metode Purpossive Sampling di 2 Kelurahan dengan mengambil 21\% dari total populasi atau sebanyak $20 \mathrm{KK}$ yang ada di Kecamatan Togo Binongko dengan pertimbangan bahwa populasi dalam penelitian ini bersifat homogen atau memiliki karakter yang sama. Variabel dalam penelitian ini yaitu karakteristik responden dan proses produksi industri pandai besi. Analisis data dalam penelitian ini menggunakan analisis deskriptif

\section{HASIL DAN PEMBAHASAN}

\section{Identitas Responden}

Identitas responden dalam penelitian ini meliputi umur responden, pendidikan, lama usaha, dan status kepemilikan lahan usaha pada Tabel 1. Salah satu ukuran kemampuan fisik seseorang adalah usianya. Bakat fisik seringkali lebih besar pada orang yang lebih muda daripada orang yang lebih tua. Karena kemampuan tenaga kerja dan manajemen yang digunakan dalam suatu perusahaan sangat terkait, usia seorang pelaku usaha dapat mempengaruhi produktivitasnya. Data 
pada Tabel 1 menunjukkan bahwa umur responden dalam penelitian ini sebagian besar masih dalam kategori umur produktif. Sebanyak 15 orang (75\%) memiliki umur antara $17-50$ tahun, sebanyak 5 orang $(25 \%)$ memiliki umur diatas 50 tahun, dan tidak terdapat responden yang memiliki umur dibawah 17 tahun. Badan Pusat Statistik (2019) menyatakan bahwa umur tenaga kerja dapat dikelompokan yaitu pada umur $\leq 17$ tahun dinamakan usia muda atau disebut usia belum produktif, umur 17-50 tahun dikatakan dewasa atau usia kerja produktif, dan umur 50 tahun keatas dinamakan usia tua atau dikatakan usia tak produktif. Hal ini menunjukan bahwa pengrajin pandai besi di Kecamatan Togo Binongko masih berada pada usia produktif. Hal ini berarti bahwa setiap pengrajin masih memiliki kemampuan untuk bekerja secara optimal dan mampu berkembang untuk mengikuti perkembangan teknologi dalam industri pandai besi. Dengan kata lain, ada kemungkinan dari pengrajin besi untuk bisa menggunakan teknologi moderen dalam usahanya yang tergolong masih tradisional.

Tabel 1. Identitas responden

\begin{tabular}{lcc} 
& \multicolumn{2}{c}{ Vesponden } \\
\cline { 2 - 3 } Umur & Jumlah (orang) & Persentase (\%) \\
17 - 50 tahun & 15 & 75 \\
$>50$ tahun & 5 & 25 \\
\hline Pendidikan & & \\
$\quad$ Tidak sekolah & 6 & 30 \\
SD & 7 & 35 \\
SMP & 6 & 30 \\
SMA & 1 & 5 \\
\hline Lama Usaha & & \\
$\leq 5$ tahun & 4 & 20 \\
6 - 20 tahun & 13 & 65 \\
$>$ 20 tahun & 3 & 15 \\
\hline Kepemilikan Lahan & & \\
Milik Sendiri & 5 & 25 \\
Milik orang lain tanpa sewa & 15 & 75 \\
\hline
\end{tabular}

Pendidikan merupakan salah satu indikator yang mencerminkan kemampuan seseorang dalam mengelola masalah, pekerjaan, dan kewajibannya. Menjalankan sebuah usaha, khususnya usaha pandai besi, membutuhkan pendidikan yang tinggi. Azmi et al. (2015) bagi industri pandai besi, tenaga kerja yang tidak sesuai dengan latar belakang pendidikan dan profesi menjadi kendala tersendiri.. Pendidikan yang memadai dapat membantu pengrajin dalam mengelola usahanya dan meningkatkan skala usaha yang dijalankannya. Data pada Tabel 1 menunjukan bahwa pendidikan responden (pengusaha pandai besi) dalam penelitian ini sebagian besar masih memiliki tingkat pendidikan setara SMP kebawah. Responden dalam penelitian ini sebanyak 6 orang (30\%) tidak pernah mengikuti pendidikan formal atau tidak tamat SD, sebanyak 7 orang (35\%) merupakan tamatan SD, 6 orang $(30 \%)$ tamatan SMP, dan hanya 1 orang $(5 \%)$ yang menjajaki jenjang pendidikan hingga SMA. Hal ini berarti tingkat pendidikan pelaku usaha pandai besi di Kecamatan Togo Binongko, Kabupaten Wakatobi masih tergolong berpendidikan rendah. Tingkat pendidikan yang tergolong rendah menjadi salah satu faktor penyebab rendahnya pengembangan usaha pandai besi dari skala kecil menjadi skala menengah ke atas. Hal ini dikarenakan pelaku usaha pandai besi hanya berperan sebagai produsen tunggal dengan sistem dan peralatan yang masih tradisional. Sedangkan urusan promosi dan pemasaran masih menggantungkan diri pada pihak ke tiga (penadah). Pendidikan yang rendah dapat mempengaruhi produsen dalam masalah promosi seperti pengetahuan dalam hal media sosial. Menurut Sudarno (2016), menyatakan bahwa tingkat pendidikan akan berpengaruh terhadap kemampuan responden dari segi pemahaman, responden, produktivitas, kreativitas dan inovasi teknologi baru untuk diterapkan dalam kegiatan usahanya, sehingga apabila tingkat pendidikan pelaku usaha rendah maka output dari usaha yang dikembangkannya akan cenderung rendah.

Pengalaman usaha sangat ditentukan oleh lama usaha. Semakin lama pengalaman seseorang dalam menjalankan usaha yang sama maka orang tersebut akan lebih baik dalam mengambil keputusan serta memanajamen usahanya. Pengalaman usaha akan diperoleh seseorang berdasarkan lama mereka bergelut dalam usaha pandai besi. Lama usaha dikategorikan menjadi 3 kategori menurut Patty and Rita (2015) yaitu usaha pemula ( $\leq 5$ tahun), usaha menengah ( $6-20$ 
tahun) dan usaha maju (>20 tahun). Data pada Tabel 1 menunjukan bahwa lama usaha yang dijalani responden dalam penelitian ini sebagian besar diatas 5 tahun. responden dalam penelitian ini sebanyak 13 orang (65\%) memiliki lama usaha $6-20$ tahun dan sebanyak 3 orang (15\%) memiliki lama usaha diatas 20 tahun. Sedangkan, responden yang menjalankan usaha kurang atau sama dengan 5 tahun hanya 4 orang (20\%). Hal ini berarti bahwa sebagian besar pengusaha pandai besi di Kecamatan Togo Binongko Kabupaten Wakatobi telah memiliki pengalaman yang mumpuni dibuktikan dengan lama usaha rata-rata diatas 5 tahun sehingga dapat memproduksi bahan baku besi menjadi alat-alat pertanian dengan baik dan mempunyai kualitas yang bagus.

Lahan merupakan salah satu aspek kunci berjalannya suatu usaha. Usaha pandai besi di Kecamatan Togo Binongko Kabupaten Wakatobi masih menjalankan usahanya dalam skala kecil, sehingga lahan yang dibutuhkan tidak luas. Meskipun begitu, kejelasan status kepemilikan lahan menjadi salah satu jaminan berkembangnya usaha yang dijalankan. Data pada Tabel 1 menunjukan bahwa lahan yang dikelola responden sebagai lahan usaha dalam penelitian ini sebagian besar berstatus pinjam tanpa sewa. responden dalam penelitian ini sebanyak 5 orang (25\%) memiliki lahan usaha sendiri, sebanyak 15 orang $(75 \%)$ meminjam lahan kerabat ataupun tetangga tanpa akad sewa atau pembayaran apapun, dan tidak terdapat responden yang menyewa lahan untuk usaha. Hal ini berarti bahwa sebagian besar pengusaha pandai besi di Kecamatan Togo Binongko Kabupaten Wakatobi menggunakan lahan non produktif yang dimiliki orang lain sebagai lahan usahanya meskipun tidak sewa atau dikenakan bayaran. Hal ini karena ada unsur gotong royong dan saling membantu yang masih dipegang teguh oleh masyarakat terutama masyarakat adat di Kecamatan Togo Binongko.

\section{Proses Produksi}

Proses produksi merupakan bagian terpenting dalam usaha guna menciptakan produk yang dapat menghasilkan keuntungan. Azmi et al. (2015) untuk menjamin kelangsungan hidup industri pandai besi dalam jangka panjang, dperlukan upaya perbaikan dalam proses produksi yaitu diberikannya kemudahan untuk memperoleh bahan baku dalam jumlah besar, meningkatkan modal melalui pinjaman individu, mengikuti pelatihan dan magang, menggunakan mesin, memasang iklan di lokasi/outlet industri.

Penggunaan bahan baku dan efisiensi penggunaan bahan baku dalam kegiatan produksi, menjadi tolak ukur dalam menghasilkan produk dengan biaya yang rendah dan dengan keuntungan yang tinggi, namun tetap memperhatikan kualitas dari produk yang dihasilkan. Talakua (2008) Perbaikan proses produksi dapat meningkatkan pendapatan industri pandai besi. Proses produksi peralatan pertanian terdiri dari beberapa tahapan, seperti pada Gambar 1.

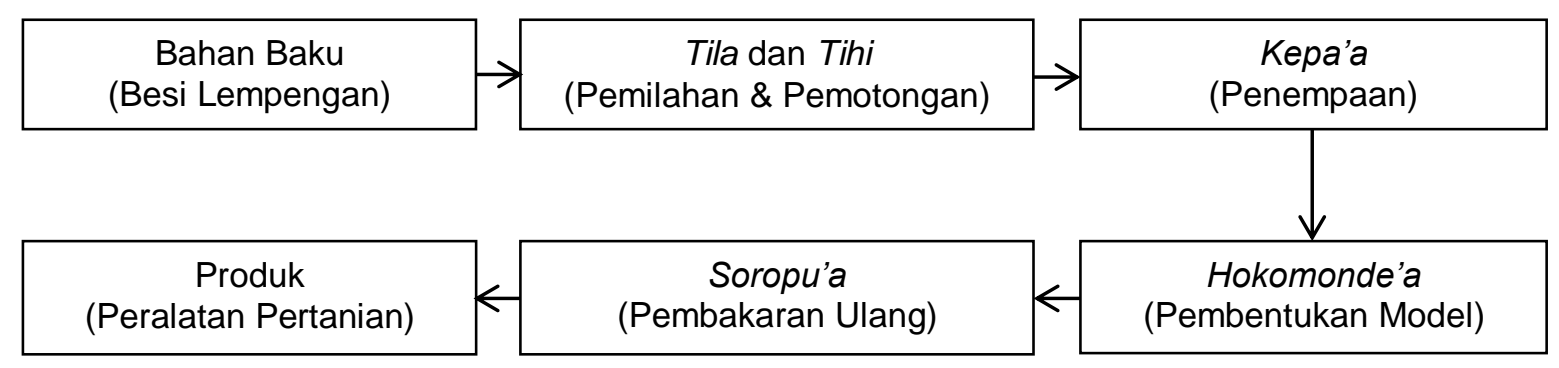

Gambar 1. Proses produksi peralatan pertanian

\section{Bahan Baku}

Bahan baku utama yang digunakan adalah besi. Azmi et al. (2015) bahan baku yang mahal, dan keterbatasan modal merupakan faktor penghambat industri pandai besi. Pengrajin besi di Kecamatan Togo Binongko memperoleh bahan baku besi dari Pulau Jawa melalui penadah khusus dari Pulau Binongko. Harga $1 \mathrm{~kg}$ besi senilai Rp10.000 - Rp13.000, dan dapat menghasilkan dua buah parang. Besi dijual dalam bentuk lempengan tipis memanjang dengan ukuran panjang 1,5 meter dan merupakan jenis besi tipe keras (besi campur baja). Bahan lain yang dibutuhkan berupa bahan bakar tungku yaitu arang yang diperoleh dari masyarakat yang melakukan usaha produksi arang kayu dengan harga senilai Rp7.000 - Rp8.000. 


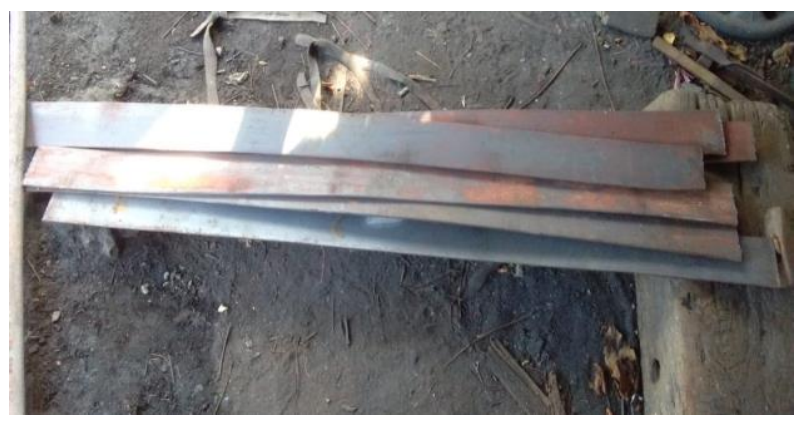

Gambar 2. Bahan baku industri pandai besi

\section{Tila dan Tihi (Pemilahan dan Pemotongan)}

Anonim (20115). membuat peralatan pertanian dengan memotong bahan lalu dipukul-pukul dengan menggunakan palu untuk menghaluskan kemudian di bakar dan di celup kedalam air. Lebih lanjut Sailon and Rizal (2014) proses pendinginan dilakukan oleh pandai besi menggunakan air. Tila dan Tihi (pemilahan dan pemotongan) merupakan tahapan awal dalam proses produksi. Pada tahap ini, bahan baku berupa besi diseleksi atau dipilah besi yang layak digunakan untuk parang sesuai dengan ukuran dan keinginan, setelah itu dilakukan pemotongan sesuai kebutuhan. Pada saat pemotongan besi, bahan baku besi terlebih dahulu dipanaskan dalam tungku pembakaran hingga panas (ditandai dengan warna besi kemerahan menyerupai arang panas). Hal ini dimaksudkan untuk memudahkan proses pemotongan dan pembentukan kembali besi sesuai dengan model parang yang diinginkan. Tungku yang digunakan masih sangat tradisional yaitu tungku dari besi atau terbuat dari drum besi bekas dengan bahan bakar berupa arang dan bantuan peniup angin menggunakan mesin blower (kipas). Proses pembakaran ini berlangsung hingga besi mencapai tingkat panas pada suhu tertentu dan besi berubah warna kemerah-merahan. Selanjutnya besi dikeluarkan dari dalam tungku untuk dipotong dan dibelah sesuai ukuran yang diinginkan. Proses ini dilakukan berulang-ulang oleh informan, dimana besi yang telah dipotong dimasukkan kembali ke dalam tungku selama lima menit hingga besi berubah warna kemerahan karena semakin lama besi dibakar kualitasnya akan semakin bagus. Besi yang telah dibakar kemudian ditempa kembali sesuai ukuran dan ketebalan yang diinginkan. Pada proses tersebut telah dapat ditentukan peralatan pertanian yang akan dibentuk. Parang merupakan peralatan pertanian yang umumnya dibuat oleh responden yang terdiri dari dua jenis parang sesuai ukurannya dan kegunaannya.

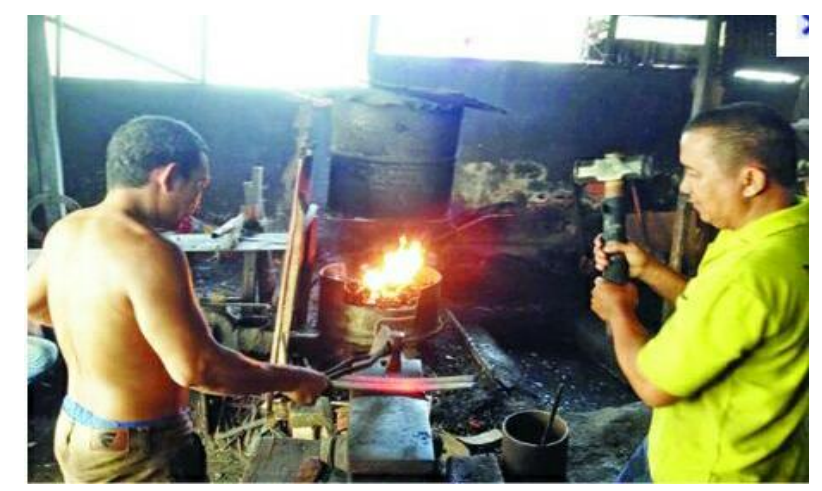

\section{Kepa'a (Penempaan)}

Gambar 3. Proses Tila dan Tihi

Besi yang telah dipotong dimasukan kembali kedalam tungku untuk dipanaskan seperti pada tahap pertama. Selanjutnya besi yang telah dipanaskan dikeluarkan dari dalam tungku dan mulai ditempa untuk mendapatkan ketebalan dan memulai pembentukan model. Model yang dibentuk sesuai keinginan responden. Penempaan dilakukan oleh dua orang pandai besi yang dikenal dengan istilah "podandhu" dimana proses ini dilakuakan dengan menempa besi yang ditempa menggunakan palu dengan berat sepuluh kilo secara bergantian dengan ritme yang teratur. Penempaan ini dilakukan bersama-sama secara bergantian dimaksudkan agar proses penempaan berlangsung cepat sehingga besi tersebut lebih cepat tertempa sebelum mendingin kembali. Pembentukan besi menjadi peralatan pertanian hanya bisa dilakukan saat besi pada tingkat panas yang tinggi (mendekati titik leleh besi). Besi dibakar berkali-kali hingga mendapatkan bentuk sempurna sesuai 
yang diinginkan responden. Semakin lama waktu pembakaran dan semakin sering dibakar, akan semakin baik peralatan yang dihasilkan. Semakin lama besi ditempa semakin bagus tingkat kekerasannya, proses ini merupakan penentu kualitas peralatan. Dalam istilah pandai besi disebut "motika", motika adalah peralatan pertanian yang tidak mudah rusak (berkualitas) dan tanah korosi. (Armila, 2018) proses penempaan yang dilakukan secara manual dapat membuat proses produksi menjadi rendah dan kualitas produk kurang baik, serta proses pengerasan logam yang dilakukan tidak sesuai dengan kaidah metalurgi sehingga produk yang dihasilkan menjadi kurang kuat dan memiliki ketahanan korosi yang rendah.

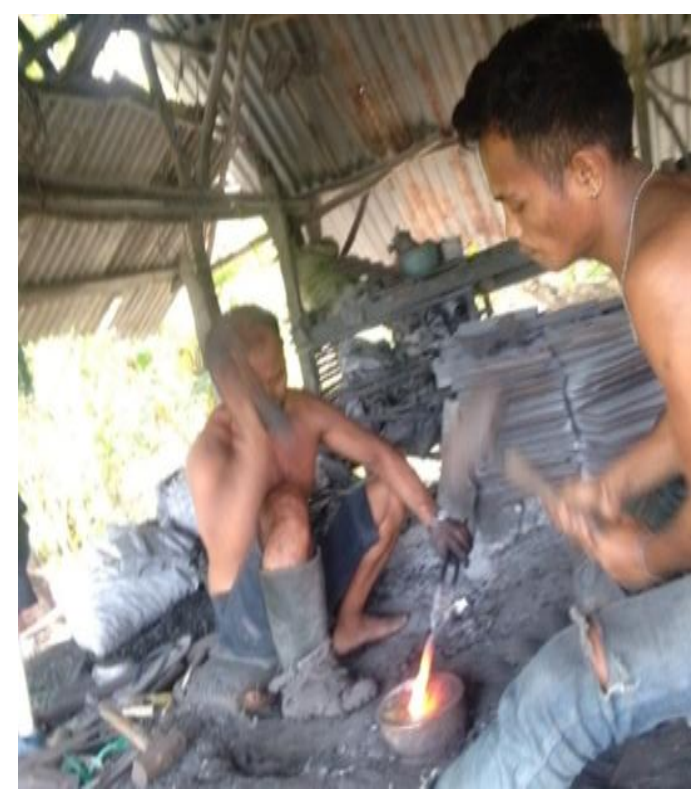

Gambar 4. Proses Kepa’a

Hokomonde'a (Pembentukan Model) dan Soropu'a (Pembakaran Ulang)

Besi yang sudah dibentuk dengan bentuk awal, kemudian dipanaskan dan ditempa hingga membentuk model sesuai dengan yang diinginkan. Penempaan berulang-ulang dilakukan untuk mendapatkan kekerasan besi yang maksimal dengan bentuk yang menarik dimana peralatan pertanian yang dibuat harus bertekstur rata begitu pula dengan bagian yang dipertajam (a'a) sampai tempat pegangan ( $u t i)$. Proses akhir terhadap peralatan yang telah siap dan halus yaitu dilakukan proses pematangan besi. Pada tahapan ini, dilakukan pembakaran ulang pada api sedang (tanpa menggunakan tungku). Hal ini dilakukan untuk meningkatkan kualitas parang agar tidak mudah patah.

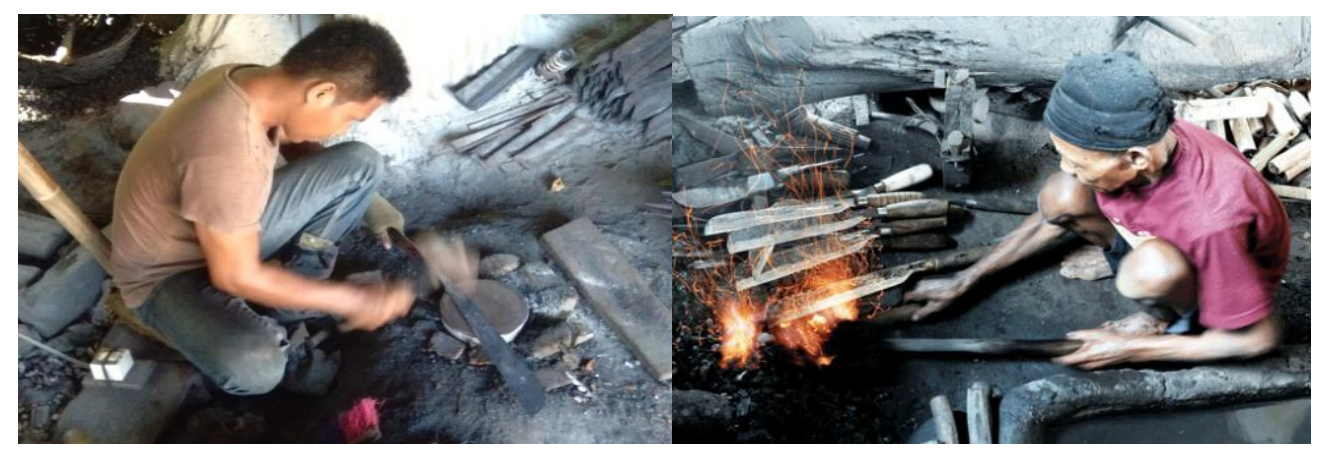

Gambar 5. Proses Hokomonde'a dan Soropu'a

\section{KESIMPULAN DAN SARAN}

Berdasarkan pembahasan dapat simpulkan bahwa peralatan pertanian yang dihasilkan oleh pandai di Kecamatan Togo Binongko dibuat melalui proses produksi yang dilakukan secara tradisional dengan tetap mempertahankan kualitas produk. Proses produksi dimulai dari Tila dan Tihi 
(pemilahan dan pemotongan bahan baku besi), Kepa'a (penempaan), Hokomonde'a (pemodelan) dan Soropu'a (pembakaran ulang). Pengrajin pandai besi dapat mempertahankan kualitas produk yang dihasilkan melalui perbaikan proses produksi dengan mengikuti pelatihan-pelatihan dan menggunakan peralatan-peralatan yang dapat meningkatkan efisiensi produksi

\section{REFERENSI}

Adiputra, M. H. (2020). Peran Pemerintah Daerah Dalam Pembinaan Usaha Mikro Kecil Danmenengah Di Kelurahan Alehanuae Kecamatan Sinjai Utarakabupaten Sinjai. Jurnal IImiah Administrasita, 11 (2).

Ahya, R., \& Lestari, M. S. (2016, 26 November 2016). Analisis Dan Penerapan Ergonomi Partisipatoripada Pengrajin Pandai Besidi Desa Carikan Sukoharjo. Prosiding Seminar Nasional Aplikasi Sains \& Teknologi (SNAST), Yogyakarta.

Anonim. (20115). Kilau Peluang Bisnis Pandai Besi. http://pandaibesiaceh.blogspot.com/2015/05/kilau-peluang-bisnis-pandai-besi.html

Armila. (2018). Dentingan Palu Tempa Pengarajin Pandai Besi Sungai Puar Mulai Sunyi. Rang Teknik Journal, 1(2). http://joernal.umsb.ac.id/index.php/Rangteknikjournal

Azmi, A. R., Hastuti, K. P., \& Anggariani, P. (2015). Upaya Pengrajin Pandai Besi Dalam Menjaga Keberlangsungan Industri Kerajinan Rumah Tangga Di Desa Tumbukan Banyu Dan Desa Sungai Pinangkecamatan Daha Selatankabupaten Hulu Sungai Selatan. JPG (Jurnal Pendidikan Geografi), 2(3), 66-801.

Patty, F. N., \& Rita, M. R. (2015). Faktor-Faktor yang Mempengaruhi Pendapatan Pedagang Kaki Lima (Studi Empiris PKL di Sepanjang Jln. Jenderal Sudirman Salatiga). Jurnal Fakultas Ekonomi dan Bisnis Universitas Kristen Satya Wacana, 5-6.

Saifuddin, S., A., M. A., \& Lukman. (2016). Aplikasi dapur pemanas bagi pengrajin pandai besi untuk meningkatkan kualitas produk alat-alat perkakas Pertanian. 14(2). https://doi.org/http://dx.doi.org/10.30811/jpl.v14i2.338

Sailon, \& Rizal, S. (2014). Analisis Perubahan Kekerasan Dan Struktur Mikro Hasil Perlakuan Panas Produk Pandai Besi Dengan Menggunakan Media Pendingin Batang Pisang. Jurnal Austenit, 6(2).

Statistik, B. P. (2019). Deskripsi Angka Beban Tanggungan. https://www.bps.go.id/istilah/index.html? Istilah_page =4

Sumanti, E. (2020). Perilaku Pengusaha (Produsen) Pandai Besi Dalam Perspektif Ekonomi Islam Di Desa Koto Padang Kota Sungai Penuh. Al-Dzahab, 1(1), 72-87.

Talakua, B. A. (2008). Pengembangan Industri Kecil Pandai Besi Dalam Menunjangpendapatan Pengusaha Kecil Di Kecamatan Leihitu Kabupaten Maluku Tengah. Jurnal Ekonomi Peluang, 2(1). 